\title{
Diet and Foraging Ecology of Fork Tailed Drongo (Dicrurusadsimilis) in Leventis Foundation Nigeria, Agricultural School South West Nigeria
}

\author{
Okosodo E.F. ${ }^{1}$,Orimaye J.O. ${ }^{2}$, Odewumi O.S ${ }^{3}$
}

\author{
${ }^{1}$ Department of Ecotourism and Wildlife Management, Federal University of Technology, PMB 1054 Akure, Ondo State, \\ Nigeria. \\ ${ }^{2}$ Forestry, Wildlife and Fisheries Management Dept, Ekiti State University, Ado-Ekiti \\ ${ }^{3}$ Department of Ecotourism and Wildlife Management, Federal University of Technology, PMB 1054 Akure, Ondo State, Nigeria
}

\begin{abstract}
This research study investigated the diet and foraging ecology of the Fork Tailed Drongo (Dicrurusadsimilis) inLeventis Foundation Nigeria Agricultural Training School, South Western Nigeria. Direct field observation method was used to collect data for 12 months on the diet and foraging ecology of these bird species. The study area was divided into three compartments according to land use types (secondary forest, Farmland and Developed Area). The result revealed that the Fork Tailed Drongo consumed variety of insects and pla nt species resources in the study area.Grasshoppers, butter flies and termites are the majorfood source and they also consumed the leaves and flowers of the Moringaoleifera and seeds, fruits of some tree species. Insect species provided the highest food source of $86 \%$ and plant species $14 \%$. The result revealed that the Fork Tailed Drongo utilized the three Compartments within the study area and that secondary forest provided highest food materials of 65\%, Farmland $23 \%$ and Developed area $12 \%$.
\end{abstract}

Keywords- Avian species, Diet, Foraging ecology, Foraging strategies, and Conservation.

\section{INTRODUCTION}

The Fork Tailed Drongo (Dicrurusadsimilis)is a small passerine bird which belongs to the family Dircruridae.The plumage is entirely black and the eye is the colour of red wine, closer inspection reveals a deeply forked tail, which is actually a result of the outer rectrices being curved at the end (Borrow and Demey, 2011).These are aggressive and fearless birds, given their small size, and will attack much larger species, including birds of birds of prey. If their nest or young are threatened. Fork Tailed Drongo live in a variety of habitats, ranging from forest to savanna and including garden and farmland in most parts of Nigeria (Elgood, 1973). It is a resident breeder in Nigeria and the bird is usually seen in pairs or small parties and only rarely in larger groups. They are fairly terrestrial, foraging on the ground in grasslands and cultivation (Chari, et al, 1982). However detailed studied on the diet and foraging ecology and is lacking in Nigeria. This paper present detailed information on the diet and foraging ecology of Fork Tailed Drongo was studied in Leventia Foundation Nigeria, Agricultural Training school Ilesa, South Western Nigeria.

\section{MATERIALS AND METHOD}

Study Area

Leventis Foundation Agricultural Training School, Ilesa is located on the former premises of the former Farm Institute Ilesa in Tropical rain forest zone with central coordinates of $078.055^{\prime} 032 \mathrm{~N}$ and $068.33 .55 \mathrm{E}$. It is about $45 \mathrm{~km}$ from Oshogbo the capital of Osun of State, Southwest Nigeria. Two rivers run across the area creating a valley of watershed and the land mass is 360 ha including the administrative blocks. The area is $360-400 \mathrm{~m}$ above the sea level which is characterized by lateritic soils, sloping topography and hydromorphic valley bottom soils typical for most of the southwestern part of Nigeria. Annual rainfall varies between 1600 and $2000 \mathrm{ml}$, mean annual temperature is $30{ }^{\circ} \mathrm{C}$ and the relative humidity is not below $40 \%$ during dry season and $100 \%$ during the wet season (Mengistu, and Salami,2007).The study site experiences a bimodal annual rainfall pattern, between April and July and from September to October, separated by dry season. Vegetation is predominantly rainforest, including wetlands along the rivers and Panicum maximum dominated open land. Among the common trees areCeltiszenkerii, 
Triplochitonscleroxylon,

Antiarisafricana,

Pycnanthusangolensis and Alstoniaboonei(Keay 1989).

Data Collection

Diet and feeding activities:

The study area was divided into three compartments according to land use types, Secondary Forest, Farmland and Developed Area. Present study on the diet and feeding ecology of Fork Tailed (DicrurusAdsimilis) was made on 36 groups ranging in size from 2 to 12 individuals. The data was collected during a continuous period of 12 months from January, to December, 2014. Direct observations method as described by (Akinpelu, 2004) was used for this study. Data were collected from the field by using binocular (Bushnell 7 x50) whenever found necessary. The observations were made early in the morning or latein the evening when common Fork Tailed are actively feeding with least disturbance to the birds. Individual groups of these birds were followed for periods varying from 2 to 6 hours. While following groups it was usually possible to keep some birds in view at all times, but rarely possible to see all members of the group together. During each scan, observations on the foraging habitat, type of feeding method employed, feeding session, size of the flock, type of diet and association with other bird species were recorded.
Seasonal changes in the feeding habits of the Fork Tailed Drongo were studied too.

\section{RESULTS}

In this study it was observed that the Fork Tailed Drongo consumed variety of food-intake through the day: Tailed Drongo was observed to plunge diving to catch small insects. They were observed to dive from the height of between 5 to $7 \mathrm{~m}$.From the result obtained it showed that the Fork Tailed Drongo consumed variety of plant and insect species. The percent of insect fed upon was higher $(86.6 \%)$ than that of than that of plant species $(14.4 \%)$. The result also revealed that butter flies constituted the dominant insect consumed (17.1\%) while Azadirachtaindica was the highest seeds consumed (5.8\%). From the result obtained in this study it showed that the Fork Tailed Drongo has the ability to consumed leaves and flowers of certain plants such as recorded on Table 2. Tanyteryspryeri was least consumed insect specieswhileFicusexapanratais the least consumed plant apecies. Fork Tailed Drongo has the ability to consumed aldult winged insects, larve and catappilar of insects and seeds, fruits, flowers and leaves of plant species.

Table 1 Insect Species consumed by Fork Tailed Drongo in the Study Area

\begin{tabular}{|c|c|c|c|c|}
\hline Common Name & Scientific Name & Family & Parts Consumed & Observations (\%) \\
\hline \multirow[t]{7}{*}{ Butter fly } & Graphiumpylades & Papilionidae & Adult winged & 5.8 \\
\hline & Papilliocynorta & Papilionidae & Adult winged & 1.3 \\
\hline & Amouristartarreu & Danaidae & Adult winged & 2.4 \\
\hline & Leptocsiamarginea & Pieridae & Adult winged & 2.2 \\
\hline & Eritismelania & Hesperidae & Adult Winged & 0.6 \\
\hline & Anthenelachares & Hesperidae & Adult Winged & 2.6 \\
\hline & Colotisevippe & pieridae & Adult winged & 2.2 \\
\hline \multirow[t]{2}{*}{ Termite } & Macrotermesbellicosus & Termitidae & Adult winged & 2.8 \\
\hline & Macrotermesnatalensis & Termitidae & Adult winged & 4.5 \\
\hline Honey Bee & Apismellifera & Apidae & Adult winged & 3.2 \\
\hline Green Bug & Nezeraviridula & Pentatomidae & Adult winged & 1.2 \\
\hline \multirow[t]{3}{*}{ Caterpillars } & Anaphavenata & Notodontidae & Whole & 2.1 \\
\hline & Anaphereticulata & Notodontidae & Larva & 2.3 \\
\hline & Anapheinfracta & Notodontidae & Larva & 1.1 \\
\hline \multirow[t]{3}{*}{ moths } & Platysphinxphyllis & $\underline{\text { Sphingidae }}$ & Ault winged & 1.6 \\
\hline & Ebodinalagoana & $\underline{\text { Tortricidae }}$ & Adult winged & 1.6 \\
\hline & Phragmataeciafuscifusa & $\underline{\text { Cossidae }}$ & Adult winged & 0.8 \\
\hline \multirow[t]{2}{*}{ Grasshoppers } & Acridiumperigrinum & Acrididae & Adult winged & 3.9 \\
\hline & Cyrtacanthacrisaeruginosa & Acrididae & Adult winged & 4.8 \\
\hline
\end{tabular}


unicolor

Schistocercagregaria

Zonocerusvariegatus

Beetles

Oryctes boas

Analeptestrifasciata

Blaps sp.

Tenebriosp

Spiders Steatodatriangulosa

Weevils Rhychophorusphoenic

Dragon fly

Tanyteryspryeri

Black ants

Campinotuspinnilucnicus
Acrididae

Pyrgomorphida

Scarabaeid

Scarabacidae

Tenebrionidae

Tenebrionidae

Theridiidae

Curculionidae

Petalurdae

Formicidae
Adult winged

9.3

Adult winged

Whole

3.7

Whole

0.4

Whole

Adult

winged/Larva

Adult winged

3.2

Adult

Adult winged

Adult winged

0.3

Adult winged

Table 2 Plant Species Consumed by Fork Tailed Drongo in the Study Area

\begin{tabular}{lllll}
\hline $\begin{array}{l}\text { Common } \\
\text { Name }\end{array}$ & Scientific Name & Family & Parts Eaten & Observations (\%) \\
\hline Moringa & Moringaoleifera & Leguminosea & leaves and flowers & $\mathbf{4 . 8}$ \\
Neam & Azadirachtaindica & Meliacea & Seeds & $\mathbf{5 . 4}$ \\
velvet fruit & Daliumqiunense & Leguminosea & seeds & $\mathbf{2 . 1}$ \\
Sweet Sap & AnnonaSenegalensis & Annonacea & Fruits and seeds & $\mathbf{0 . 4}$ \\
Ficus & Ficuspolita & Euphorbiaceae & Fruits and seeds & $\mathbf{0 . 9}$ \\
Ficus & Ficusexasprata & Euphorbiaceae & Fruits and seeds & $\mathbf{1 . 3}$ \\
& & & & 14.9
\end{tabular}

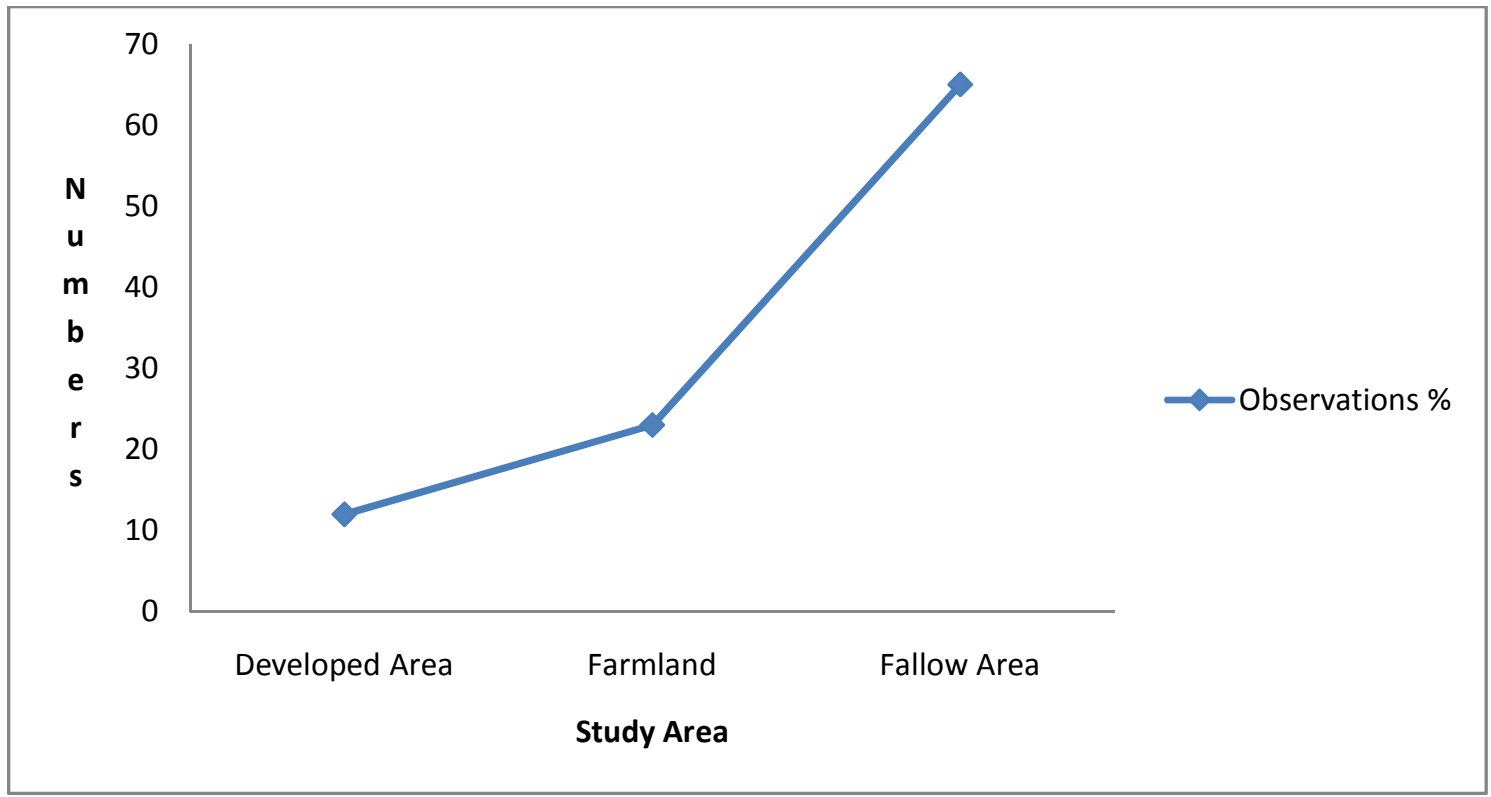

Fig.1: Percentage Utilization of Different Compartments in the study Area 


\section{DISCUSSION}

This study provides the first detailed description of the diet and foraging behaviour of the Fork Tailed Drongo in Nigeria It found that the Fork Tailed Drongo has a broad diet, consisting largely of insects and plant species. Among the most noticeable food consumed are GraphiumpyladesMacrotermesbellicosusMacrotermesnatal ensisSchistocercagregariaMoringaoleifera were PapilionidaeTermitidaeAcrididae and Leguminosea. These bird species are known to feed comprehensively on insects (Mathew, et al, 1978) and seeds. Fruits, leaves and flowers of some plant species (Butler et al. 2005). From this study it was observed the Fork Tailed Drongo utilized three different habitats in the study area.it was observed to perched on electricity wire lines in the developed area and three branches shrubs in the rest compartments. This is in agreement with Lammers and Collopy (2007) who stated that avian predators are attracted to over-head utility power lines because they provide perches for various activities, including hunting prey. Brookers et al. (1990), and Yosef (2004) also documented the importance of perches for prey detection / hunting, vigilance, resting as well as other activities of insectivorous birds. From the field observations, Fork Tailed Drongo utilized the Forest compartment more than the rest compartments were there are tall trees of about 16 to $23 \mathrm{~m}$ in height. This suggests that the Fork Tailed Drongo derived $65 \%$ its food resources from the forest $23 \%$ from the farm land and $12 \%$ from the Developed Area. This is consistent with (Robinson and Holmes 1984). Who reported that vegetation structure, plant species composition, prey abundance and distribution, and interspecific competition significantly affect the foraging height selection of insectivorous bird species They further stated that three major foraging substrates, namely air, plants and ground, were recognized of which, the White-breasted Kingfisher, Indian Roller and Black Drongo fell under the plant guild because plant offers a greater variety of insect food (Morse, 1977). Gokula and Vijayan (2007) reported that birds took insect prey in various foraging substrates which are paddy and other crops, small stumpy vegetation, and trees, from both habitats. The Fork Tailed Drongo was observed during both breeding and nonbreeding seasons, from the field observations during breeding season, nesting activities is always sited close to wetland, forest and farms. This observations is in agreement withPidgeonet al. (2003) stated that micro-habitat and vegetative composition around nesting tree are important factors in relation to nest placement and success of avian species. The micro-habitat and vegetation in the habitat not only provide nesting-site and food but also fibers, twigs, grasses for nest construction..Fork Tailed Drongo is selective in their diet. From field observation it was noted that these bird species does not consumed all insects and fruits, seeds and flowers in the wild. This consistent with Royama, (1970) who reported that many bird species often feed selectively, and utilizes such factors as prey palatability, nutritive value, abundance and prey size and hardness. It appears that, though birds were living in suburban areas, they were still more dependent on wild plant species for food as compared to other frugivorous birds, thus causing minimal harm to human crops (Dhind,andSaini, 1994). The consumption of leaves and flowers of MoringaOleifera,was an interesting observation because leaf consumption is common not in birds. This is consistent with Anthal, and Sadi, (2013) who reported the consumption of leaves by Jungle Babbler (Turdoidesstriatussindianus). Feeding in these birds occurs intermittently throughout the day. The intensity of foodintake gets accelerated from the awakening after the reconnection calls and then gradually slows down. During dry season days, they start feeding in early hours (0600 to 0630 hours) but during wet season days, it starts as late as 0730 hours. The concentration of food intake again increases around 1430 hours in the dry season and 1530 hours in wet season. They spend on an average $62.2 \%$ of the day time for feeding in dry season (average day length-12 hours) and $56.12 \%$ in wet season (average day length-11 hours). Light rain showers are no obstacle for feeding to these birds but feeding activities are restricted during heavy rainfall. Many species of birds spend more than $50 \%$ of their day foraging and feeding, particularly in the morning and evening. This observation is in agreement with Kelly (1998) who stated that weather, especially temperature, affects the foraging behavior of insectivorous birds. Several studies have found temperature-related changes in the foraging behavior of birds and Gokula and Vijayan (2007) stated that food availability, habitat structure, and interspecific competition are also responsible for variation in the foraging behavior of birds.

In conclusion, many factors, such as time of day, season, ambient temperature, availability of prey, breeding season,and presence of predators, influence the foraging behavior of birds.

\section{CONCLUSION}

The results of this study clearly indicate that Fork Tailed Drongo consumed both insects and plantspecies resources available to them in the study area. But, compared to plant 
species foods resources there variety of insect food resources which are mainly consumed in larger proportions. The Fork Tailed Drongo therefore help in the control and keep check on various harmful insects like grasshoppers, termites, caterpillars etc., which are injurious to the agricultural crops, stored grains and to some extent dispersal of seeds, The Fork Tailed Drongo are useful species for farmers.

\section{ACKNOWLEDGMENTS}

The authors are very grateful to the staff and management of Leventis Foundation Nigeria Ltd/gte, Agricultural Training School for their support during the period of the study.

\section{REFERENCES}

[1] Akinpelu, A.I. \& O.A. Oyedipe. 2004. A Twelvemonth field study of the West African Thrush Turduspelios(Passeriformes: Muscicapidae). Part 1: food and feeding ecology. Rev. Biol. Trop. 52: 10011007.

[2] Anthal A. and Sahi D.N. Food and Feeding Ecology of Jungle Babbler, Turdoidesstriatussindianus (Ticehurst) in District Jammu (J\&K), India International Research Journal of Environment Sciences ISSN 2319-1414 Vol. 2(7), 54-57,

[3] Asokan, S. and A.M.S. Ah, 2010. Foraging behavior of selected insectivorous birds in Cauvery Delta region of Nagapattinam District, Tamil Nadu, India. J. Threat. Taxa, 2(2): 690-694.

[4] Butler, S.J., M.J. Whittingham, J.L. Quinn \& W. Cresswell (2005).Quantifying the interaction between food density and habitatstructure in determining patch selection.Animal Behaviour69: 337-343.

[5] Brookers, M.G., R.W. Braithwaite \& J.A. Estbergs (1990).Foraging ecology of some insectivorous and nectarivorous species of birds in forests and woodlands of the wet-dry tropics of Australia. Еmu 90: 215-230.

[6] Borrow, Nik and Demey Ron. (2012). "A guide to the birds of western Africa”.Princeton University Press

[7] Chari, N., J.R.N. Rao, R. RameshandG. Sattiah, 1982.Comparative studies on flight characteristics, moment of intertia and flight behaviour of two flycatchers, Dicrurusadsimilis and Meropsorientalis.Indian J. Experi. Biol., 20: 894-896.

[8] Dhind, M. S. and Saini, H. K. (1994) Agricultural ornithology: an Indian perspective. J. Biosci. 19: 391402.
[9] Elgood, J.H., C.H. Fry \& R.J. Dowsett. 1973. African migrants in Nigeria. Ibis 108: 84-116.

[10] Gokula, V. \& L. Vijayan (2007). Foraging strategies of birds in partitioning of food resources in dry deciduous forest of Mudumalai Wildlife Sanctuary, Tamil Nadu, India.Journal of Scientific Transaction in Environment and Technovation1(1): 36-42.

[11] Kelly, J. (1998). Behaviour and energy budgets of Belted Kingfishers in winter.Journal of Field Ornithology 69: 75-84.

[12] Keay.R.W.J.,(1989), Trees of Nigeria. A review version of Nigerian trees $(1960,1964)$ by R. W. J Keay, C. F. AOnochie and D. P Strandfield. Claridon Press Oxford University press: Pp 476 pp.

[13] Lammers, W. \& M.W. Collopy (2007).Effectiveness of avian predator perch deterrents on electric transmission Lines.Journal of Wildlife Management 71(8): 2752-2758.

[14] Mathew, D.N., T.C. Narendran and V.J. Zacharias, 1978.A comparative study of the feeding habits of certain species of Indian birds affecting agriculture. J. Bombay Nat. Hist. Soc., 75: 1178-1197

[15] Mengistu, and Salami . (2007). Application of remote sensing and GIS inland use/land cover mapping and change detection in a part of south western Nigeria. African Journal of Environmental Science and Technology Vol. 1 (5), pp. 099 -109.

[16] Morse, D.H (1977) Feeding behavior and predator avoidances in heterospecific groups.BioScience, pp.332-339

[17] Pidgeon, A.M., V.C. Radeloff and N.E. Mathews 2003 Landscape scale patterns of Black-throated Sparrow abundance and nest success. Ecol. Applic., 13: 530-542.

[18] Robinsons, K. \& R.T. Holmes (1984).Foraging behavior of forest birds: the relationships among search tactics, diet and habitat structure.Ecology 63: 1918-1931.

[19] Royama. T. 1970. Factors governing the hunting behaviour and selection of food by the great tit (Paris major L.). Journal of Animal Ecology 39(3): 619.668.

[20] Yosef, R. (2004). Perch-site use and inter- and intraspecific aggression of migratory Brown Shrikes (Laniuscristatus) in Southern Taiwan. Biological Letter 4 (2): 113-118. 